\title{
Gifted Children and Adolescents: Exploring the Perspective of a Group That Still Needs Educational Attention in Brazil
}

\author{
Cristina M. Delou1,2*, Fernanda S. Cardosoํ, Ruth Mariani' ${ }^{1}$, Izabel C. P. Paixão1, \\ Helena C. Castro ${ }^{1,2}$ \\ ${ }^{1}$ Programa de Pós Graduação em Ciências e Biotecnologia-PPBI, Institute of Biology, Fluminense Federal \\ University, Niterói, Brazil \\ ${ }^{2}$ Curso de Mestrado Profissional em Diversidade e Inclusão-CMPDI, Institute of Biology, Fluminense Federal \\ University, Niterói, Brazil \\ Email: ${ }^{*}$ cristinadelou@globo.com
}

Received 7 June 2014; revised 8 July 2014; accepted 15 July 2014

Copyright $@ 2014$ by authors and Scientific Research Publishing Inc.

This work is licensed under the Creative Commons Attribution International License (CC BY). http://creativecommons.org/licenses/by/4.0/

(c) (i) Open Access

\begin{abstract}
Gifted and talented children are known as those with a valuable potential that may be stimulated to the benefit of humankind. However, in many countries they are known as those that don't need any specialized educational assistance or stimulation or even worse that they do not exist. In Brazil, the educational Laws recognize this group, but the Brazilian educational system still struggles to properly attend them. Unfortunately, most teachers and professors that are supposed to help this group to get the best of their giftedness and high skills for the good of these kids and humankind, currently ignore them. In 2012 there was the 1st Meeting of Gifted Children and Adolescents sponsored by the Brazilian Council of Giftedness. During this meeting 21 gifted and talented children and adolescents have prepared a document called Declaration of the Gifted Brazilian Child to inform about their expectations and how the society may help them. This gifted group created 8 statements that now we have analyzed and discussed, considering their ideas, the logistics of attending their needs and the limit of these requirements considering Brazilian laws and World rights. According to our results these kids know what they need, what is missing and what they lose when getting no proper educational attention. The maturity of their requests revealed the lack of a proper formation of our professionals involved in their education that ignore and/or suffocate them and their potential knowledge, which may affect not only their future but also the Brazilian development and innovation capacity.
\end{abstract}

${ }^{*}$ Corresponding author.

How to cite this paper: Delou, C. M., Cardoso, F. S., Mariani, R., Paixão, I. C. P., \& Castro, H. C. (2014). Gifted Children and Adolescents: Exploring the Perspective of a Group That Still Needs Educational Attention in Brazil. Creative Education, 5, 1224-1234. http://dx.doi.org/10.4236/ce.2014.513138 


\section{Keywords}

\section{Gifted, High Skills, Teaching, Educational Needs}

\section{Introduction}

Despite that they are not synonymous, some terms including gifted, highly gifted, precocious, early developers, intellectually precocious, talented, bright, geniuses, prodigies, or with high-level potentialities, high intellectual potential, high skills have been used to name individuals with a developed potential. According to Vaivre-Douret (2002, 2004, 2011), the potentialities of a gifted individual refer to potential skills, talents, and abilities that can be triggered to develop in certain circumstances related to issues of feasibility, implementation, and motivation.

The research and studies about gifted people early date from the 19th century with Lombroso (1891) until now with the World Council for Gifted and Talented Children (WorldGifted, 2014). Currently, gifted individuals are those who present a high Intelligence Quotient (IQ) determined from rigorous evaluation tests such as Wechsler Preschool and Primary School Intelligence scale (WPPSI, 2004) and the Wechsler Intelligence Scale for Children (WISC, 2005) conducted by a clinical psychologist. According to the literature, these classic tests measure three types of intelligence (linguistic, spatial, and logicomathematical) in contrast to what is currently pointed as more appropriate by other authors such as Gardner that points the multiple intelligences theory as more feasible to identify them (Gardner, 1983).

From studies with patients with brain damage, Gardner described seven types of intelligence that are independent one from another (linguistic, logicomathematical, visuospatial, musical, somatokinetic, interpersonal, and introspective). This author also developed the nonquantifiable notion of the emotional quotient (EQ) that integrates the emotional and affective experience of the individual (Gardner, 1983; Vaivre-Douret, 2011). Some authors agreed that IQ tests together with other tests approaching the psychoaffective sphere including personality and/or neuropsychological tests may be more adequate to identify gifted individuals (1999, apud Vaivre-Douret, 2011). Creativity has been also another feature considered in the perspective of the identification of gifted individuals (Torrance, 1972; Guilford, 1975; Lubart et al., 2003; Lubart \& Georgsdottir, 2004; Vaivre-Douret, 2011; Besançon, 2013).

The literature shows neuro, social and psychological studies that suggest that some gifted children present "adult-like" brain activity but without an adult social behavior. This affects the development of this group and characterizes them as a public with special educational needs (Koziol et al., 2010; Simoes et al., 2010; VaivreDouret, 2011; Duan \& Shi, 2014; Kostogianni \& Andronikof, 2014).

In Brazil, the gifted individuals are mentioned in the educational laws. The national politics of special education presented by the Brazilian Ministry of Education recognizes the existence of gifted students due to their special needs. The government rules their right to the access of a proper education through the Law of Guidelines and Bases (LDB) of 1996. Initially they were called gifted (Brazil, 1994) and lately by the high skills/ gifted (Brazil, 2001a: Art. 5, III; 2008, 2009: Art. 4º III) and high skills or gifted students (Brazil, 2011). According to the Brazilian Law the students with High Skills/Giftedness present "high potential and great involvement in the areas of human knowledge, isolated or combined including intellectual, leadership, psychomotor, arts and creativity" (Brazil, 2009: Art. $4^{\circ}$, III).

In the Brazilian history, the Society has noticed giftedness in a perspective of a privilege, which does not need any type of specialized care. This behavior has generated disaffection and non-attendance to that public, including the inappropriate recommendation of gifted students to centers of care focused on cognitive impairment and/ or behavioral problems (São Paulo, 2008).

Initially, the Salamanca Statement (Salamanca, 1994) and then the LDB (Brazil, 1996) pointed the educational programs and system as responsible for not only considering the student diversity and their characteristics but also attending their specific needs. The Salamanca Statement emphasizes the congregation of the international community, particularly governments with international cooperation programs, international funding agencies, especially those responsible for the World Conference on Education for All, UNESCO, UNICEF, UNDP and the World Bank to endorse the perspective of inclusive education and to support the development of special education as an integral part of all education programs (Brazil, 1994). 
In 1996, LDB established that, when necessary, there should be specialized support services in regular school to meet the peculiarities of groups with special needs (Brazil, 1996). All these services and care should be extended to the gifted students, due to the fact that these students have specific educational needs and motivations (Mori, 2009). According to Pérez \& Freitas (2011) it is important to provide opportunities for the proper development of students potentials through appropriate educational alternatives.

Despite the Brazilian laws, rules and educational guiding lines and documents, the access to a proper educational service by the gifted students is compromised by several factors. One of the most important is the inappropriate approach (e.g. Superficially or inadequately) on this topic in the academic disciplines and training programs of academic degree courses at universities and colleges that prepare teachers and professors. This feature does not allow proper understanding of these future professionals about the work that must be conducted with these students (Pérez \& Freitas, 2011).

The Brazilian Council for Giftedness (CONBRASD) is a non-governmental, non-profit organization built by individuals and corporations of all states interested in contributing to the defense of the rights of Persons with High Skills/Giftedness (CONBRASD, 2014). Among its purposes involving this group are included: 1) Sensitize the community to recognize the situations and issues concerning this group; 2) Collaborate with those responsible to formulate and promote public policies regarding this group for public and private entities; 3) Assemble groups to establish exchange of knowledge and experiences, coordinating their efforts, studies and actions; 4) Encourage exchanges and cooperation among professionals and public and private national and international entities to deal with giftdness related issues; 5) Promote conferences, seminars, symposia, meetings, conferences, lectures, courses, and other similar activities concerning this theme; 6) Encourage studies and research on topics related to this theme; 7) Encourage the formation and training of human resources for education, research, identification and care of this group and their families; 8) Encourage the establishment of a Central Data and Information about this theme, as well as its development; 9) Create, maintain and release publications related to these topics; 10) Request, receive and apply for contributions, donations, legacies, grants and financial resources from individuals and public or private, national or international organizations, to carry out the purposes in favor of this group and 11) Develop other activities related to the achievement of these purposes of this council (CONBRASD, 2014).

The Brazilian Council for Giftedness promotes its national meeting bi-annually in a different region of Brazil each time. In 2012, it held its Fifth National Meeting at Federal Fluminense University in Rio de Janeiro State as well as the First Meeting of Gifted Children and Adolescents. At that time, a group of 21 gifted children and adolescents attended the event (Figure 1) and created at the end of this meeting a Declaration where they cited their needs and expectations. The analysis of this declaration gives us an opportunity of reviewing the needs of the Brazilian gifted children and adolescents from their own perspective, pointing to the issues that should be addressed, improved and/or fixed in their educational assistance.

\section{Methodology}

In this research, we analyzed the declaration prepared by 21 gifted children and adolescents of both sexes, from public and private schools, aged 10 to 22 years and including a deaf female gifted student during the First Meeting of gifted Children and Adolescents in 2012 (Figure 1). The presentation of the Declaration by these students was filmed on video and is available on the Federal Fluminense University site (http://ufftube.uff.br/video/3NK2B3X2H5GH/Encontro-Nacional-do-Conselho-Brasileiro-de-Superdotação-Part e-5). It is composed of eight statements (Table 1) and was freely constructed with the unique instruction: the gifted children and adolescent should prepare a document to inform others about what the gifted people need and what is important to them. Each statement was analyzed and assessed considering three indicators including the level of administration required to attend them, the professionals required, the feasibility of execution and the direct relation with the current Brazilian laws produced by the Ministry of Education and Culture and worldwide documents (Brazil, 2001a, 2009).

\section{Results and Discussion}

In this work we evaluated the declaration of Brazilian gifted Children and Adolescents constructed in 2012 by 21 gifted children and adolescents during the First Meeting of gifted Children and Adolescents at Rio de Janeiro state in Brazil (Figure 1). The declaration is composed of eight statements that involved different issues and that 


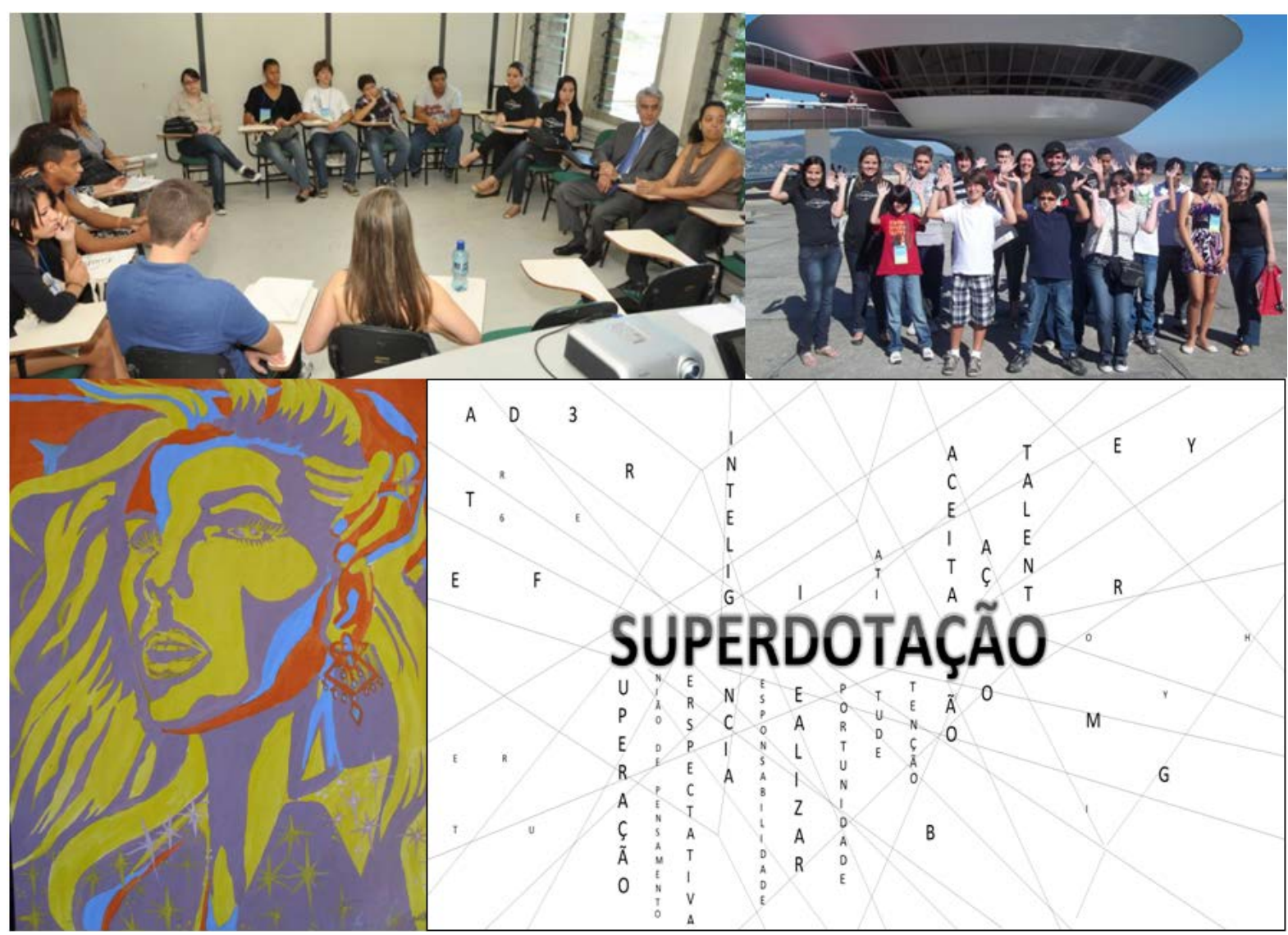

Figure 1. 1st Meeting of Gifted Children and Adolescents in 2012 at Rio de Janeiro state, Brazil. (A) Gifted group during talking with Dr. Nickolas Colangelo, Professor of Gifted Education at the University of Iowa e Dr. Helena Carla Castro, coordinator of Post-graduation Program in Sciences and Biotechnology from Federal Fluminense University; (B) Gifted Group visiting touristic places of Niteroi city during the meeting; (C) Drawing of one of the Gifted children that attended the meeting; (D) Drawing of one of the Gifted Children that produced it during the meeting to represent the complexity of the main theme (Giftedness = Superdotação) and other related themes (Overcoming = Superação, Linked Thoughts = União de Pensamentos, Perspective $=$ Perspectiva, Intelligence $=$ Inteligência, Responsibility $=$ Resposabilidade, Idealize-Idealizar, Opportunity $=$ Oportunidade, Atitude $=$ Atitude, Attention $=$ Atenção, Acceptance $=$ Aceitação, Action $=$ Ação, Talent $=$ Talento).

require different levels of the educational, health and research Brazilian systems to be fulfilled (Table 1). We will discuss this declaration point by point in order to evaluate the perception of these young people about their own situation in Brazil.

\section{1. $1^{\text {st }}$ Statement: Students with High Skills/Giftedness Require the Assistance of Resource/Support Rooms Together with Their Family and Teachers to Support Their Creativity and Skills Development}

The resource/support room is a space in the Brazilian school with a variety of pedagogic tools and strategies in order to properly assist the diversity of the scholar groups with different special needs (Mori \& Brandao, 2009). Besides the specialized space/environment, this room should have a specialized teacher who knows how to do all the specific assistance requested by these groups. According to the LDB (Brazil, 1996), at the schools that the students care is not feasible in regular classes, it should be performed at these Resources/Support Rooms.

In 2006, the Brazilian Ministry of Education created the Nuclei of Activities for High Skills/Giftedness (NAAH/S) in partnership with all Brazilian States Departments of Education. For that purpose these nuclei should provide instructional resources, including didactical and pedagogical materials, also training professionals with technical expertise to meet the academic and social-emotional challenges of gifted students. The organization of these nuclei occurs at the Multifunction Resources Rooms of these schools where this public should 
Table 1. The eight statements of the declaration constructed in 2012 by 21 gifted children and adolescents during the First Meeting of gifted Children and Adolescents in Rio de Janeiro state, Brazil.

\begin{tabular}{ccc}
\hline \# & Statement & $\begin{array}{c}\text { Level of Administration/ } \\
\text { Professional required }\end{array}$ \\
\hline
\end{tabular}

1 Students with High Skills/Giftedness require the assistance of resource/support rooms together with their family and teachers to support their creativity and skills development.

School, Home/Teachers, Family

It is essential to prepare teachers and other education professionals to identify students

2 with giftedness and/or vocation in different areas as many of us are not identified, and their skills are not developed.

3 It is necessary that school gives the support to the families of the students with High Skills/Giftedness in order to educate and help them to deal with the situation.

\section{University and Colleges/} Professors

School, Home, NAAH/S Teachers and Psychologists

4 Individuals with High Skills/Giftedness need psychological support at an emotional level as many of them suffer bullying and abuse at school and cannot handle the situation.

5 Increase the inclusion of students with High Skills/Giftedness at universities, given their development and since they require a greater contact with the academic life.

6 Promoting more meetings for those with High Skills/Giftedness at a younger age, to establish greater integration of this specific community as well as debates and research.

7 Creating strategies to promote private inclusion of students with High Skills/Giftedness in the labor market, offering resources for the development of business skills.

Local governments should provide resources to individuals with High Skills/Giftedness

8 specific to the development of their potential, particularly in non-developed and non-urban areas where local schools do not present the resource/support rooms and/or specialized professionals.
School and Health system/ Teachers and Psychologists

Universities, Research Facilities/ Professors, Researchers

CONBRASD, Brazilian Ministries of Education and of Science and Technology, Universities, Schools

Industry and research facilities/ Businessman and Researchers

Governments and Schools/Mayors and Governors

find activities that will stimulate their creativity and capacity for critical thinking. These nuclei should provide learning that these students will not find in the traditional classrooms. Besides attending these students, these centers also should provide pedagogical support to their teachers and guidance to their families, assuring the identity of the inclusive, democratic and accessible schools (Brazil, 2001b, 2006; São Paulo, 2008; Mori, 2009).

According to the Guidelines of the Ministry of Education for the implementation of NAAH/S (Brazil, 2006), their main goals are: to promote the identification, care and development of students with High Skills/Giftedness at public elementary schools, enabling the effective inclusion in the mainstream of Brazilian education. In addition, these nuclei should disseminate knowledge on this subject in the educational system, to the school communities and families in all states and the Federal District. They should provide instructional and learning resources and training professionals with technical expertise to meet the academic and social-emotional challenges of individuals with high skills/ giftedness.

This Brazilian guidelines document also emphasizes that the full gifted student development depends on the involvement of the whole community in the process. However, according Alencar (2012) "in Brazil there is resistance to the implementation of special programs for gifted individuals and several misconceptions remain in our society". This is a factor which hinders the implementation of the proposed project since many educational professionals are not prepared to properly identify and send the gifted to students these nuclei.

Thus, it is important to implement a policy that is not only focused on the physical organization of space, but also in the awareness and training of professionals so they will know not only how to deal with these students in this space as well as how to carry out the work and projects with them. Since the importance of the teacher and the family are reinforced in the next statements we will explored these perspectives when getting on them.

\section{2. $2^{\text {nd }}$ Statement: It Is Essential to Prepare Teachers and Other Educational \\ Professionals to Identify Students with Giftedness and/or the Vocation in Different Areas, since Many of Us Are Not Identified, and Their Skills Are Not Being Developed}

According to Pérez, the insipid and/or superficial or even incorrect approach of the giftedness in the academic 
education does not allow the proper understanding of the future teachers about the work that must be developed with the gifted students (Pérez \& Freitas, 2011). The gifted students emphasized in their declaration the importance of preparing our future teachers so they know activities that provide a differentiated work that will meet this group expectations.

According to several authors, we need to identify the skilled individuals early within the classrooms. On that matter the society needs professionals that are able to do it properly to direct them to the specific assistance and/or to develop activities in the classroom that give them the opportunity of developing their real potentials (Pinto, 1933; Vaivre-Douret, 2011). The scholar system in Brazil still works with the common and uniform teaching way offering the exact same instruction for all children when in fact it's essential to offer the same opportunities as a starting point but without limiting the knowledge growth capacity of each student.

Among the tasks of a teacher of gifted children are not only planning challenging lessons and assignments, but developing and learning innovative methods for helping on this public teaching-learning process. It also requires producing and searching for materials and resources as well as inviting people to stimulate creativity and interest as well as to develop discipline, accountability, productivity, and leadership skills. The opportunities and difficulties of having these high skills should be also taught to not only the gifted children but also their parents. The assistance about career choices should not be forgotten for the older ones.

It is therefore important to emphasize that all degree courses involving the formation of teachers and professors in any level should address the issue "Students with High Skills/Giftedness in Classrooms" consistently, effectively and efficiently clarifying the teacher's work and consequently improving the quality of attending these students at schools. According to Freitas et al. (2012), the society requires teachers and professors who recognize and respond to the gifted students' needs, considering their different potentials, styles and rates of learning. In addition a more flexible and appropriate curriculum to lead to heterogeneous pedagogical practices is also required. Thus the teacher may execute the predetermined curricula, but choosing activities, contents or experiences that best suit the development of all students, including the gifted ones.

\section{3. $3^{\text {rd }}$ Statement: It Is Necessary That School Gives the Support to the Families of the Students with High Skills/Giftedness in Order to Educate and Help Them to Deal with the Situation}

The most common complaints of Brazilian parents about their gifted sons and/or daughters include the "family weariness" caused by their excessive questioning. Guimarães \& Alencar (2013) described that knowing that their child is different can be a very anxious experience to these parents. For some parents, the diagnosis is a total surprise, whereas to others, it is the unpleasant confirmation.

The literature describes two different reactions of parents of gifted students when knowing about their gifted kids. The first reaction is when parents express pride, mainly focusing on what these children produce. It's a delicate situation as they do not want their children to fail because they are gifted. The parents reaction may lead to a non positive behavior from the gifted child, including inhibition, isolation, insecurity and/or feeling of being misunderstood that, without psychological support, may lead to great suffering for the children (Rosenberg, 1978; Fleith, 2009).

Another common reaction among parents of gifted children is the denial of these children's potential even when noticing their over expressed skills. Often this reaction is due to these parents' beliefs on their inability of attending their own children. However, it is important for gifted children to be accepted by their parents and that should encourage their talent. Such parents will have to learn new strategies for: 1) socializing with these children, 2) exercising their sense of humor 3) lowering their impatience and irritation, 4) accepting their own limits regarding the authority over them and 5) admitting that the gifted child needs independence, especially intellectually. These new learning will benefit the parents personal development as well as their role as a parent (Novaes, 1999).

According to Prista (2007), there is no need to invest in special schools or classrooms for the gifted students. Instead a huge investment should be made in the educator formation since once well-prepared educators and experts are in the resource/support rooms at the schools, they will be able to support the parents and help them to understand how to deal with their gifted children. It is therefore a very important strategy for the education of this gifted public that the school supports their families. 


\section{4. $4^{\text {th }}$ Statement: Individuals with High Skills/Giftedness Need Psychological Support at an Emotional Level as Many of Them Suffer Bullying and Abuse at School and Cannot Handle the Situation}

Paulo Freire (1980) argues that the Brazilian schools adopt an educational system that increasingly contributes to processes of exclusion of many students, including the gifted students. The learning environment is limited in terms of knowledge construction and creativity maintenance where many individuals with high skills/giftdness cannot understand themselves and/or their capacity on structuring their own lives and role in the society (Gonçalves \& Fleith, 2013). In addition, it is very common at conferences and seminars regarding this theme to describe the gifted people as objects without personal needs, which is also a common practice at schools. However, the educational professionals should understand that these individuals also need to live socially with different people, including those comparable to them in terms of intellectual and creative abilities as well as with people with lower and even higher capacity and skills (Prista, 2007).

It is also important for the school to avoid the productivity and competitive environment so these children may be seeing as equal to their other peers. On that purpose, the school should estimulate the children's imagination and the creativity (Alencar \& Fleith, 1987). Therefore, focusing on the real needs of this group, the teacher may offer a proper education that makes students think and produce and not just play and get bored, and most important, among their peers, gifted or not, being respected in their thinking and learning (UNESCO, 2007).

Dalosto (2011) emphasized that the prejudice against the gifted children comes first from themselves that do not want to be either different or differentiated from the other students. Thus, the work with these individuals needs to stimulate them to the self-knowledge so they can get along with themselves and other students.

\section{5. $5^{\text {th }}$ Statement: Increase the Inclusion of Students with High Skills/Giftedness at Universities, Due to Their Development Needs and Their Requirements for a Greater Contact with the Academic Life}

The scholar inclusion is a process that should attend the particularities of each student. Thus, a student with High Skills/Giftedness only will be effectively included in the teaching process when they have access to real opportunities to develop their potentials. This is called as reverse inclusion where the students once enrolled in the regular school system are obligated to receive their curriculum enrichment outside of their regular classroom environmental activities (Delou, 2001).

The Decree No. 7611/2011 (Brazil, 2011) argues that the nuclei of accessibility in federal institutions of higher education should be structured and organized to attend people with disabilities and/or special needs including those with High Skills/Giftedness. Thus, one of the roles of the Brazilian universities and research centers is to create spaces to support the gifted students from elementary and high schools. Literature emphasizes that schools should seek to interact through NAAH/S with higher education institutions or institutes that develop and promote research, arts and/or sports.

Since specialized education can be done both inside and outside the school, this may include students of higher education and different activities financed by Foundation for the Development of Basic Education (FUNDEB) that supports the schools' requests. In Brazil, this financing is linked to the registrations' proof of the gifted student through the school census/MEC/INEP (Brazil, 2009: Art. 8) and the approval of its pedagogical program (Brazil, 2011: Art. 4, § 2).

Freitas and Pérez (2012) also reported the concern about taking the proper care of students with high skills/ gifted or they may stagnate and often becoming disinterested with the context of the classroom. Sabatella \& Cupertino (2007) discussed that the role of the scholar programs associated with universities and research facilities is to fulfill and complement the gifted children need allowing their personal development and creating opportunities to find challenges compatible with these special group skills. This is a way of investing in this group education as well as in the preparation of future professionals of our country. Sabatella (2008) explained that all developed countries are aware and taking care of this group with specific and special programs that valorize them. It is clear that our country needs to work on the human resources also at the level of the gifted children with specific politics and promoting the development of a new culture with access to proper education, science, technology and better formed professionals (Santos apud Prista, 2007). 


\section{6. $6^{\text {th }}$ Statement: Promoting More Meetings for Those Identified with High Skills/Giftedness since at a Younger Age, to Establish Greater Integration of This Specific Community as Well as Debates and Research}

Group team work is of great importance to all individuals as a factor of evolution. It is the opportunity to be recognized as part of a group, accepting each other, having autonomy and cooperation at the same time and also structuring a collective space with its own self-regulating movement (Prista, 2007; Smith, 2008).

One of the activities that could be proposed by the universities to assist students with High Skills/Giftedness is to create a space to discuss about topics of their interest including inviting researchers and young students of higher education. The promotion of some meetings so they can express their feelings, doubts, anxieties may also be a targeted event that could be performed in the classrooms at the university itself or spaces in the partner schools, interested in promoting these great opportunities for their students. Unfortunately, often due to the limited mobility, students drop out of the proposed activities. Thus, one strategy to favor these meetings currently is to use virtual/computational tools.

The Brazilian reports about gifted children and young people show that sometimes, at the very beginning, this group works without much structure, which generates anxiety and irritation. However, as soon as the main objectives of the meetings are established, and each individual finds its own path, such feelings decrease and group identity is established (Prista, 2007). The group interaction is the best way for developing creativity and fulfilling this commitment with learning that guarantees the entire education-communication process according to Smith (2008). This process is quite transcendent since pedagogical relationships do not end in themselves, but are the matrix of what is desired for social relationships.

\section{7. $7^{\text {th }}$ Statement: Creating Strategies to Promote Private Inclusion of Students with High Skills/Giftedness in the Labor Market, Offering Resources for the Development of Business Skills}

According to Nizam Guanaes (Embassador of UNESCO), the current world educational system is a factory for preparing unemployed people, since it does not take into account the demands of the labor market, does not cultivate the spirit of initiative and innovation or the desire to learn the new and accomplish viable and productive projects in society (Moreira \& Stoltz, 2012). This statement leads us to think about Brazilian schools and how they are on this path by not recognizing the overall students' talents including the gifted students. Our educational system is not applying strategies that encourage this group to the research development area, avoiding the preparation of gifted professionals with excellence in research and development of projects to the labor market.

At same time, it is essential that Brazilian companies create spaces for favoring exchanges with schools. The absence of this exchange fails to create opportunities for individuals who have a large commitment to the industrial tasks and high creativity, manifested by the high level of fluency of ideas, and thought flexibility and originality, as well as receptiveness to new activities, thoughts, actions and products; sensitivity to details; aesthetic sense and divergent thinking (Renzulli \& Reis, 1997).

Brazil has the worst rate of interest in science among the countries of Latin America according to the Iberoamerican Network of Science and Technology of Argentina report (IBMR, 2011). Probably this is because scientific research is presented as something far from the Brazilian student's reality. This presentation also gives the wrong idea that science within companies is something impossible to achieve. Therefore, many students lose their interest in scientific development as there are no real experiences or opportunities in their school life that support their vocational perspectives to this area.

The UNESCO document (2007) emphasizes that it is necessary to bring man closer to its real world. In the case of individuals with High Skills/Giftedness and above-average potential, there is the possibility of creating conditions for dynamic and creative exchanges, preventing them to be those disturbing or a small isolated genius in a room, building gadgets and useless programs on their computer.

\section{8. $8^{\text {th }}$ Statement: Local Governments Should Provide Resources to Individuals with High Skills/Giftedness Specific to the Development of Their Potential, Particularly in Non-Developed and/or Non-Urban Areas Where Local Schools Do Not Present the Resource/Support Rooms and/or Specialized Professionals}

The creation and support of specific projects that target students with special needs and identify the individuals 
with High Skills/Giftedness among them are supported by the Brazilian law. As an example, the National Education Plan approved by Law no. 10.172/01 (Brazil, 2001c) established twenty-seven goals and objectives for assuring the education of people with special educational needs. One of them is the development of educational programs in all counties with partnership with health and social assistance areas, aiming to increase their care supply from early childhood education to their professional training.

In order to be effective, it is necessary to establish a partnership between the schools of Brazilian Basic Education (Elementary and High Schools) and the centers for caring for individuals with High Skills/Giftedness (Brazil, 2007). Our Educational systems must enroll all students and ensure the necessary conditions to offer a quality education whereas the schools should take good care of them. These Educational systems should meet the demand through the creation of information systems and interface with government agencies responsible for the School and demographic Census to meet all the criteria necessary to achieve a high quality training program for these gifted students (Brazil, 2001b).

The evaluation of gifted children's statement makes clear that it is necessary that the government supports the development of programs for students with special needs, including those with high skill/giftedness pointing to the lack of support to develop their potentialities (Brazil, 2001b).

\subsection{Overall Analysis of the Gifted Children and Adolescents Declaration}

The overall analysis of the declaration revealed that the gifted children and teenagers who participated in this first meeting, despite of their younger age, were able to cover most of the issues that are directly or indirectly related to the success or failure of their educational development (Table 1). They covered from personal issues to work subjects with a detailed and very mature approach, which confirmed the literature regarding about capacity of solving problems that interest them. To fulfill the expectations of this group, which is reflected in the eight statements, it will need the participation of different spheres and levels of the Brazilian educational system and human resources (family, teachers, professors, psychologists, businessman and researchers) coming from their own home to the universities, industry, research facilities and the Brazilian Ministries of Education and of Science and Technology (Table 1).

\section{Conclusion}

According to our data, the analysis of the Declaration prepared by this gifted group is reinforced by the report to UNESCO of the International Commission on Education for the twenty-first century: "The Treasure Education" (2007) says that clear manifestations of human freedom are threatened by the standardization of the individual behavior. Both social and economic innovations are of particular importance and for that purpose, imagination and creativity should be stimulated. The twenty-first century needs this diversity of talents and personalities, which reinforced the necessity of providing for gifted children and young people experiences involving discovery and experimentation (aesthetic, artistic, sporting, scientific, cultural and social). This implies a collective work, with the collaboration of parents on shaping the schooling of their children, besides well-prepared teachers for helping families and gifted children who cannot deal with this particular situation, implementing programs that meet the peculiarities of these individuals also properly preparing the educational professionals and those directly involved in the educational activities of this group.

\section{Acknowledgements}

We thank PROPPI-UFF, FAPERJ, CAPES and CNPq for the financial support of this research.

\section{References}

Besançon, M. (2013). Creativity, Gitdness and Education. Gifted and Talented International, 28, 149-162.

Brazil (1994). Declaração de Salamanca. http://portal.mec.gov.br/seesp/arquivos/pdf/salamanca.pdf

Brazil (1996). Lei de Diretrizes e Bases da Educação Nacional. Brasília. http://portal.mec.gov.br/arquivos/pdf/ldb.pdf

Brazil (2001a). Parecer CNE/CEB02_2001. http://portal.mec.gov.br/cne/arquivos/pdf/ceb02_2001.pdf

Brazil (2001b). Diretrizes Curriculares Nacionais para a Educação Especial.

http://portal.mec.gov.br/CNE/arquivos/pdf/CEB017 2001.pdf 
Brazil (2001c). Plano Nacional de Educação. WWW.planalto.gov.br/ccivil_03/leis/leis_2001/10172.htm

Brazil (2006). Resolução CEE/CP no 7 de 15 de dezembro de 2006. http://portal.mec.gov.br/CNE/arquivos/pdf/CEE/CP7_2001.pdf

Brazil (2007). A Construção de Práticas Educacionais para Alunos com Altas Habilidades/Superdotação (Vol. 1). Brasília, DF: Orientação para Professores.

Brazil (2009). Resolução No. 4, de 2 de outubro de 2009. Institui as Diretrizes Operacionais para o Atendimento Educacional Especializado na Educação Básica, na modalidade Educação Especial. Conselho Nacional de Educação/Câmara de Educação Básica, 2009.

Brazil (2011). Casa Civil da Presidência Da República.

CONBRASD (2014) Brazilian Council for Giftedness. http://conbrasd.org/wp

Dalosto, M. M. (2011). O aluno com altas habilidades/superdotação e o bullying: Manifestações, prevalências e impactos. Dissertação de Mestrado, Brasilia: Universidade Católica de Brasília, Programa de Pós-Graduação Stricto Sensu em Educação.

Delou, C. M. C. (2001). Sucesso e fracasso escolar de alunos considerados superdotados: um estudo sobre a trajetória escolar de alunos que receberam atendimento em sala de recursos de escolas da rede pública de ensino. Tese (Doutorado em Educação), São Paulo: Pontifícia Universidade Católica de São Paulo.

Duan, X., \& Shi, J. (2014). Attentional Switching in Intellectually Gifted and Average Children: Effects on Performance and ERP.

Fleith, D. S. (2009). A contribuição do psicólogo escolar para o desenvolvimento das altas habilidades. In C. M. MarinhoAraújo (Ed.), Psicologia escolar: novos cenários e contextos de pesquisa, formação e prática (pp. 361-362). Campinas: Átomo \& Alínea.

Freire, P. (1980). Conscientização. São Paulo: Ed. Moraes.

Freitas, S. N., \& Pérez, S. G. P. B. (2012). Altas habilidades/superdotação: atendimento especializado (2nd ed.). Marília: ABPEE.

Freitas, S. N., Romanowski, C. L., \& Costa, L. (2012). Alunos com Altas Habilidades/Superdotação no Contexto da Educação Especial. In L. C. Moreira, \& T. Stoltz (Eds.), Altas Habilidades/Superdotação. Talento, Dotação e Educação (pp. 237-250). Curitiba: Juruá.

Gardner, H. (1983). Frame of Mind: The Theory of Multiple Intelligences. New York, NY: Basic Book.

Gonçalves, F. C., \& Fleith, D. S. (2013). O que alunas superdotadas e não superdotadas pensam sobre inteligência e criatividade. In D. S. Fleith, \& E. M. L. S. Alencar (Eds.), Superdotados: Trajetórias de Desenvolvimento e Realizações (pp.25-39). Curitiba: Juruá.

Guilford, J. P. (1975). Varieties of Creative Giftedness: Their Measure and Development. Gifted Child Quarterly, 19, 107-121.

Guimarães, T. G., \& Alencar, E. M. L. S. (2013). Estudo de Caso de um Aluno com Características de Superdotação e Transtorno de Asperger. In D. S. Fleith, \& E. M. L. S. Alencar (Eds.), Superdotados: Trajetórias de Desenvolvimento e Realizações (pp. 109-120). Curitiba: Juruá,.

IBMR (2011) Você sabe como despertar em seus alunos o gosto pela pesquisa científica? http://www.contosdaescola.net/voce-sabe-como-despertar-em-seus-alunos-o-gosto-pela-pesquisa-cientifica/

Kostogianni, N., \& Andronikof, A. (2014). Self-Esteem and Giftedness: A Rorschach Comprehensive System Study. Encephale, 40, 3-8. http://dx.doi.org/10.1016/j.encep.2013.01.001

Koziol, L. F., Budding, D. E., \& Chidekel, D. (2010). Adaptation, Expertise, and Giftedness: Towards an Understanding of Cortical, Subcortical, and Cerebellar Network Contributions. Cerebellum, 9, 499-529.

http://dx.doi.org/10.1007/s12311-010-0192-7

Lombroso, C. (1891). The Man of Genius. London: W. Scott.

Lubart, T. I., \& Georgsdottir, A. S. (2004). Créativité, haut potentiel et talent. Psychologie Française, 49, $277-291$. http://dx.doi.org/10.1016/j.psfr.2004.05.005

Lubart, T. I., Mouchiroud, C., Tordjman, S., \& Zenasni, F. (2003). Psychologie de la Créativité. Paris: Armand Colin.

Mori, N. N. R., \& Brandao, S. H. A. (2009). O atendimento em salas de recursos para alunos com altas habilidades/superdotação: O caso do Paraná. Marília, Revista Brasileira de Educação Especial, 15.

http://www.scielo.br/scielo.php?script-sci_arttext\&pid=S1413-65382009000300011\$lng=en\&nrm=iso

Novaes, M. H. (1999). O desenvolvimento psicológico do superdotado. São Paulo: Atlas.

Pérez, S. G. P. B., \& Freitas, S. N. (2011). Encaminhamentos pedagógicos com alunos com Altas Habilidades/Superdotação 
na Educação Básica: O cenário Brazileiro. Educar em Revista, Curitiba, n. 41. http://www.scielo.br/scileo.php?script=sci_arttext\&pid=S0104-40602011000300008\&lng=en\&nrm=iso

Pinto, E. (1933). O problema da Educação dos Bem Dotados. São Paulo: Companhia do Melhoramento.

Prista, R. M. (2007). Superdotados \& Psicomotricidade: A Complexidade Humana em questão (1st ed.). revisada e atualizada. Rio de Janeiro: Ed. Léon Denis.

Renzulli, J., \& Reis, S. (1997). The Schoolwide Enrichement Model: A How-To Guide for Educational Excellente. Mansfield Center, CT: Creative Learning Press.

Rosenberg, R. L. (1978). Psicologia dos Superdotados. Rio de Janeiro: José Olympio.

Sabatella, M. L. P. (2008). Talento e Superdotação: Problema ou Solução (2 ed.). Curitiba: Ibpex.

Sabatella, M. L., \& Cupertino, C. M. B. (2007). Práticas Educacionais de Atendimento ao Aluno com altas Habilidades/Superdotação. In D. S. Fleith (Ed.), A construção de práticas educacionais para alunos com altas habilidades/superdotação: Orientação a professores (Vol. 1, pp. 299-318). Brasília: Ministério da Educação, Secretaria de Educação Especial.

São Paulo (2008). Um olhar para as altas habilidades: Construindo caminhos. São Paulo: Secretaria de Educação, CENP/CAPE. Christina Menna Barreto Cupertino (org).

Simoes, L. I., Lowenthal, L., Lefebvre, L., \& Vaivre-Douret, L. (2010). Etude des caractéristiques psychologiques, physiologiques et sociales des enfants à haut potentiel. Enfance, 1, 27-44. http://dx.doi.org/10.4074/S0013754510001047

Smith, D. D. (2008). Introdução à Educação Especial: Ensinar em Tempos de Inclusão (5 ed.). Porto Alegre: ARTMED.

Torrance, E. P. (1972). Tests de Pensée Créative. Paris: Centre de Psychologie Appliquée.

UNESCO (2007). Educação um Tesouro a Descobrir. São Paulo: Ed. Cortez.

Vaivre-Douret, L. (2002). Le développement de l'enfant aux “aptitudes hautement performantes” (surdoués): Importance des fonctions neuropsychomotrices. Approche Neuropsychologique des Apprentissages chez l'Enfant, 67, 95-100.

Vaivre-Douret, L. (2004). Les caractéristiques développementales d'un échantillon d'enfants tout venant à "hautes potentialités” (surdoués): Suivi prophylactique. Neuropsychiatrie de l'Enfance et de l'Adolescence, 52, 129-141.

http://dx.doi.org/10.1016/j.neurenf.2004.01.006

Vaivre-Douret, L. (2011). Developmental and Cognitive Characteristics of “High-Level Potentialities” (Highly Gifted) Children. International Journal of Pediatrics, 2011, Article ID: 420297. http://dx.doi.org/10.1155/2011/420297

WISC-IV. Weschler Intelligence Scale for Children (2005). Echelle d'Intelligence de Wechsler pour Enfants et Adolescents (4th ed.). Paris: Centre de Psychologie Appliquée.

WorldGifted (2014). WorldGifted Newsletters of the World Council for Gifted and Talented Children. 2, 1-12. http://www.world-gifted.org/sites/default/files/WG322.pdf

WPPSI. Wechsler Preschool and Primary School Intelligence Scale (2004). Echelle d'Intelligence de Wechsler pour la Période Pré-Scolaire et Primaire (3rd ed.). Paris: Centre de Psychologie Appliquée. 
Scientific Research Publishing (SCIRP) is one of the largest Open Access journal publishers. It is currently publishing more than 200 open access, online, peer-reviewed journals covering a wide range of academic disciplines. SCIRP serves the worldwide academic communities and contributes to the progress and application of science with its publication.

Other selected journals from SCIRP are listed as below. Submit your manuscript to us via either submit@scirp.org or Online Submission Portal.
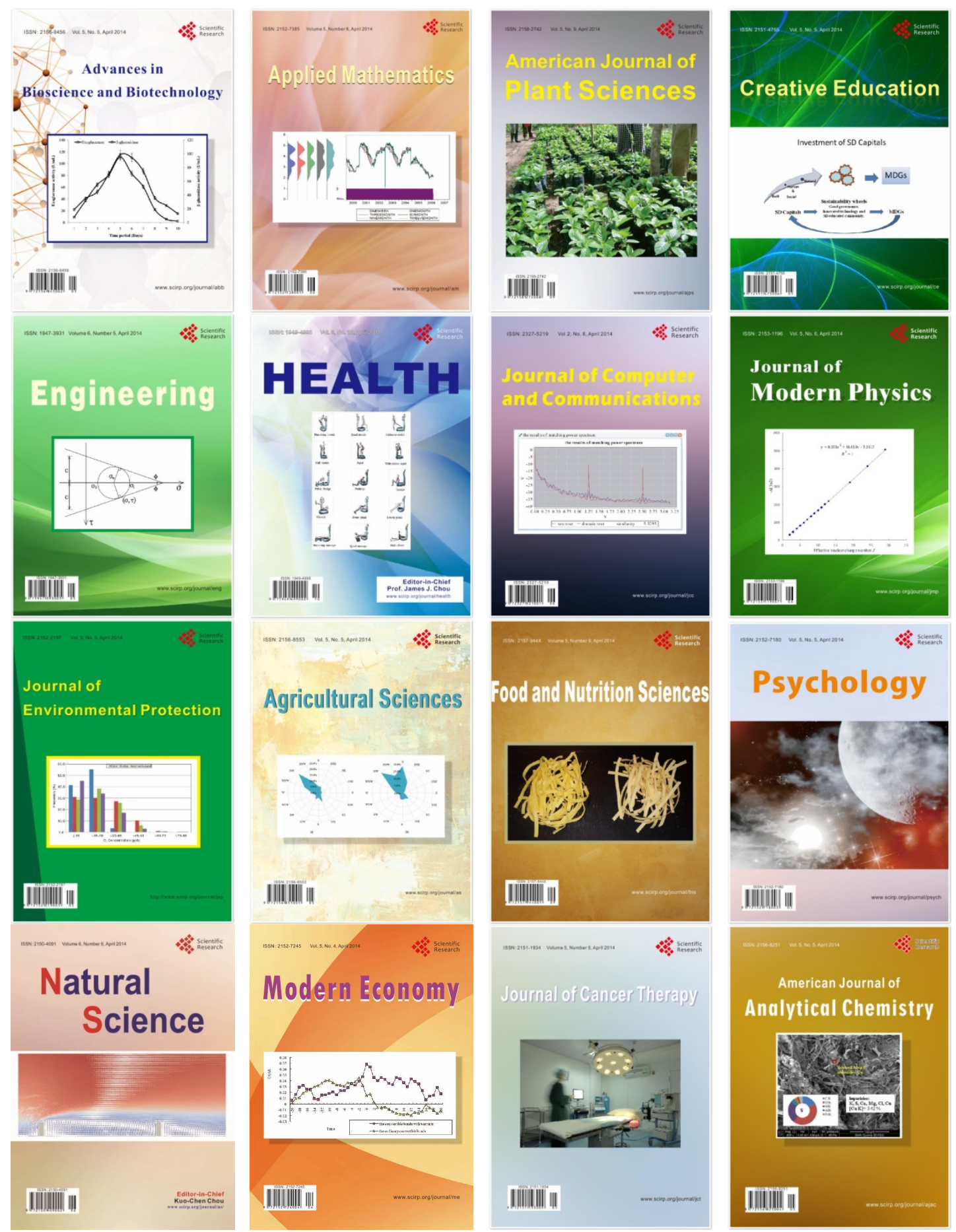